\title{
Determinants of Domestic Tourism Growth in India
}

\author{
Radhika B. Nair ${ }^{1}$ and Jayalakshmy Ramachandran ${ }^{2 *}$ \\ ${ }^{1}$ Research Scholar, The University of Nottingham, Jalan Broga, 42500 Seminyih, Malaysia \\ ${ }^{2}$ Assistant Professor, The University of Nottingham, Jalan Broga, 42500 Seminyih, Malaysia
}

\section{Abstract}

In this paper we aim to empirically identify the determinants of tourist destinantion by domestic tourists that leads to growth of tourism in Indiagers in India . Our sample, broadly. from the south revealed that climate and destination management inclusive of destination marketing and image had influenced the choice of consumers. The findings are significant in policy implications, particularly for the tour managers as well as advertising agennts and to a certain extent in government policies. In particular, we urge the Ministry of tourism to price tourism pacakges based on affordability of the consumers through discounts and promotional offers.

Keywords: Domestic, Tourism, Sustainable, Destination, Growth

\section{Introduction}

Introduced as an economic activity in the 1950's in its second five year plan, Indian tourism has inspired a number of people from within and outside India to experience unfamiliar cultural, adventurous, social and business engrossments. Within India the people intended to travel to eother visit friends or relatives or pilgrimage and learning (Abhyankar, 2013). History shows that the settings up of facilities like accommodation and inns (Dharamsalas) were mainly to facilitate traders. The broadening of tourism to hill stations like Kashmir (Kumar, 2008) as well as the introduction of Indian Tourism Development Corporation (ITDC) in 1966 followed by progression in transportation as well as communication systems helped to advance the tourism industry (Novelli et al., 2006; Chaudhary, 2000). Thus theimmense expansion of domestic tourism in the country over the years has led the culturally, linguistically, religiously diverse nation to act in unison and strengthen its rich heritage. Campaigns like "Incredible India" have further provided the momentum for the tourism industry in the country (KPMG Report, 2013). The tourism industry is thriving in India largely because of the domestic travelers that has accounted for almost 30 million domestic tourists every year. The past years have seen a soar in the tourism sector, mainly contributed by domestic tourism with an estimate of 1282 million travelers in 2014 contributing to approximately $12 \%$ annual growth in domestic tourism. This has led to enhancement in other economic activities such as job opportunities, infrastructure development, improvement in communication channels and attempts to alleviate poverty.

Despite tremendous contributions to national development and integrity, the contributions made by domestic tourism and measures for sustainability, has gone unnoticed in the planning process (Juvan and Dolnicar, 2014; Sin 2009). As rightly pointed out by a former tourism minister of India Mr. Jagmohan, many countries fail to realize that domestic tourism should be the base of the pyramid for international tourism. Through this paper, we attempt to shed light the unexplored expanses of domestic tourism in India.

*Email: jayalakshmy.rama@nottingham.edu.my 


\section{Domestic Tourism in India}

Tourism in India has observed a paradigm shift to include a wide range, of which wildlife, medical, adventure, pilgrim tourism are a few. The states that received the maximum domestic tourist visits were Andhra Pradesh at $20 \%$ of the total share, closely followed by Tamil Nadu and Uttar Pradesh at $17.8 \%$ and $16.2 \%$. It is also noteworthy that throughout the course of the recession, domestic tourism in India never subsided and had a growth of $18.8 \%$ unlike the negative growth of $2.2 \%$ witnessed from Foreign Tourist Arrivals in the country.

A number of econometric models had been developed previously in tourism literature (Baloglu and McCleary, 1999; Eymann and Ronning, 1997). Koppelman (1980) was of the opinion that the current models are not sensitive to the strategies that can be formulated to influence or motivate travel behaviour and also, they ignore the tourist's attitudes like personal feelings towards a service or destination. This was the void in tourism research as pointed by Papatheodorou (2001). The motive behind tourism and choice of destinations thus needs to be explored. Every tourist has an option to choose the destinations based on the vivid range of products and services to attract tourists (Crompton, 1992). The norm that influences the process includes personal (push) factors and destination (pull) factors (Hsu et al., 2009). Numerous factors like age, destination marketing and image, climate, etc. might have an influence on destination choice. Increasing awareness amongst people has routed travelers to choose locations that have sustainable practices as their travel destinations. Customer loyalty increases, as it creates a positive experience for both the tourists and the host community. Furthermore, the future of a number of existing tourist attractions depends heavily on sustainable practices and from this perspective, researchers, politicians and tourism providers collectively have all accepted that sustainable practices in tourism of India are inevitable for survival.

Tourism in the early 90's bestowed little attention to climate and also, the literature on climatic changes gave little attention to its impact on tourism (Witt and
Witt, 1995; Smith et al., 2001).Incorporating climate variables in the study of choice of destination have become common since the $21^{\text {st }}$ century (Amelung et al. 2007; Goh, 2012; Lise and Tol, 2002). Rosselló-Nadal, (2014) suggests that the climate is a good indicator of tourist arrivals.. Although the variation in tourism and the choice of destinations due to climate change is small, its impact in the future is predicted to be phenomenal. Studies by Berrittella et al., (2006) have concluded that by 2050 climatic influence on tourism and thereby on GDP would be 0.3 to $0.5 \%$. Domestic travel is also influenced by the climate of a particular host region. The degree of satisfaction, influence on tourism infrastructure like transportation and communication systems have all been influenced by climate of a destination (Martin, 2005).We, therefore hypothesise that climate at a destination influences the choice of a destination for sustainable tourism in Indian domestic tourism.

Although the amalgamation of goods and services make comprehending price to a destination complex, literatures dating back to the 1990's have successfully argued the role of price in the choice of a tourist destination. The influential roles played by substitutes and compliments to a potential traveler are also well regarded in literatures (Crouch, 1994). This not only helps tourism providers set a suitable pricing strategy, but also helps them manage and promote their destination product or services effectively (Jimenez et al., 2009). Previous literatures in this discipline have also tried to analyze the various demand elasticities like cross price elasticity, own price elasticity and income elasticity. The rise in the demand for package tours is an indicator of the consciousness to reduce the net price (Raikkonen and Honkanen, 2013). We, therefore, hypothesise that price plays an important role in choice of destination by consumers.

Competition in the tourism market place happens with regard to the perceived image of each place (Baloglu and Mangaloglu, 2001). Consequently, this perceived image can be a crucial factor in the choice of sustainable tourist destinations by potential tourists. From a service provider's perspective, it is an essential element in establishing the competitive advantage. Given 
its relevance, destination management, inclusive of the destination image and destination marketing is one of the most explored areas of research (Tapachai and Waryszak, 2000). Destination marketing via visual and print media has an influence in shaping the image of a destination. Thus, destination management with a focus on destination image and marketing play a pivotal role in deciding on the destination of a tourist's choice. The application of this in Indian domestic tourism is an interesting aspect to be explored given the dearth in literatures concentrating on India. We further hypothesise that marketing of specific destination will influence the choice of consumers in India.

\section{Research Design}

We use quantitative research method. We use questionnaire method. The research population for this study consists of people from India. South India was chosen as the desired region to conduct the research because of their contribution to domestic tourism (Indian Tourism Statistics, 2015). It is home to a large number of culturally different people from various parts of the country (Eswarappa, 2007) and incorporates a variety of tourist attractions (Salter, 2012; Sharma, 2007). Men and women aged above 20 earning an income or having had earned an income previously, were targeted. We used five point likert scale ranging from strongly disagree (1 point) to strongly agree ( 5 point).A snowball sampling was used to collect the necessary data. All the classes of the society based on income were encouraged to participate.The technique of forming and structuring a questionnaire contributes to the reliability and validity of the data collected (Saunders et al., 2003). A common technique to identify reliability of the data is by using Cronbach's alpha reported in Table 1.

A total of 328 questionnaires were collected respondents. Nonetheless, 47 questionnaires were unfinished and there-

Table 1. Reliability statistics

\begin{tabular}{lcc}
\hline \multicolumn{1}{c}{ Reliability statistics } & cronbach's Alpha & Number of Item \\
\hline Climatic Factor & 0.624 & 4 \\
Price Factor & 0.775 & 6 \\
Destination & 0.797 & 8 \\
Management Factor & & \\
Sustainability Factor & 0.695 & 7 \\
\hline
\end{tabular}

fore had to be discarded. Finally, 281 responsesavailable sorted, cleaned and analysed. Following the data cleaing the desired factors and strong loadings were reported. Items that loaded on factors with a value of 0.45 and above were retained as the sample size is high (Cua et al., 2001). According to Comrey and Lee (1992), items that loaded below 0.45 were considered poor, and anything above that value was considered good (Krank et al., 2011). Finally, we had 25 items that formed the model. Correlation tests were satisfactory and inter corelations issues were tackled. Kaiser-Meyer-Olkin (KMO), Bartlett's test of sphericity measurements and eigenvalue determination were performed and all the three supported the suitability of conducting a factor analysis. The factor loadings and mean scores revealed that all the three factors were important in attracting domestic travellers

\section{Regression Analysis}

In order to ensure an accurate understanding and analysis of the regression model, it is critical to test for normality, homoscedasticity of residuals, independence of residuals, multi-collinearity and linearity. All the tests were assesses and passed to proceed with regression analysis. Corresponding to the statistical model, there is just one equation (where $\mathrm{X}$ represents the predictor) that is formed which is:

$$
\mathrm{Y}=\beta_{\mathrm{o}}+\beta_{1} \mathrm{X}_{1}+\beta_{2} \mathrm{X}_{2}+\beta_{3} \mathrm{X}_{3}
$$

Where: $\mathrm{X}_{1}$ is theclimatic factor

$\mathrm{X} 2$ is the price factor

$\mathrm{X} 3$ is the marketing of specific destination

$\mathrm{Y}$ is the dependent variable of choice of

domestic tourist destination for sustainable tourism

Running the multiple regression analysis for the model with 281 data, the $\mathrm{R}^{2}$ is found to be 0.491 and the adjusted $R^{2}$ is 0.485 (Table 2) at a significance of 0.000 . An adjusted $R^{2}$ value of 0.485 is considered a reasonable model in social science studies as the size of the population is usually large (Studenmund, 2001). Thus, the data collected is quite well explanatory of the model under research.

In the Anova Table 2, model is significant at 0.000 which is less than the $5 \%(0.000<0.05)$ significance 
level at $\mathrm{F}$ of 89.016 proving that the statistical model is a good fit for analysis. The Table 3 shows that two of the three independent variables (Climate and marketing of specific destination) have a linear relationship with the dependent variable as they are significant at the $5 \%$ significance level. There is no multi-collinearity problem occurring as all independent variables have a VIF value of less than 2 and a tolerance greater than 0.5 which indicates that the dependent variable can be explained appropriately by the independent variables.

In conclusion, two variables (Climate and Marketing of destination ) have linear relationships to the choice of a domestic destination for sustainable tourism at $\operatorname{sig} \mathrm{t}<$ 0.05 . The multiple regression equation is as follows:

$$
\mathrm{Y}=1.9998 \mathrm{E}-016+0.108 \mathrm{X} 1+0.611 \mathrm{X} 3
$$

The first hypothesis was, thereby, supported which agreed with the previous findings of Maddison, (2001)

Table 2. Model summary

\begin{tabular}{cccccc}
\multicolumn{7}{c}{ Modal Summary $^{\mathrm{b}}$} \\
\hline Model & $\mathrm{R}$ & R square & $\begin{array}{c}\text { Adjusted } \mathrm{R} \\
\text { Square }\end{array}$ & $\begin{array}{c}\text { Std.Error of the } \\
\text { Estimate }\end{array}$ & $\begin{array}{c}\text { Durbin- } \\
\text { Watson }\end{array}$ \\
\hline 1 & $.701^{\mathrm{a}}$ & .491 & .485 & .71739875 & 1.688 \\
\hline
\end{tabular}

a. Predictors: (Constant), Destination Management Factor, Climatic Factor, Price Factor b. Dependent Variable: sustainability Factor

Table 3. ANOVA of the model

\begin{tabular}{lccccc}
\multicolumn{8}{c}{ ANOVA $^{\mathrm{a}}$} \\
\hline Model & Sum of Square & df & Mean Square & F & sig. \\
\hline 1 Regression & 137.439 & 3 & 45.813 & 89.016 & $.000^{\mathrm{b}}$ \\
Residual & 142.561 & 277 & .515 & & \\
Total & 280.000 & 280 & & & \\
\hline
\end{tabular}

a. Dependent Variable: Sustainability Factor

b Predictors: (Constant), Destination Management Factor, Climatic Factor, Price and Martin (2005) that climatic conditions influenced tourist's choice of domestic travel and in our case it was a positive influence. However, Hypothesis 2 was not supported in the Indian tourism market and disagreed with the previous findings of Edwards (1995) and Crouch (1994) that price has an influence on a tourist's choice of destination.Finally, Hypothesis 3 was supported and agreed with the previous findings of Buhalis, (2000) and Lee et al et al., (2008) that marketing of particular destination influences the choicedestination by consumers.

Further, using a descriptive statistics to analyse the preference of Indian tourists towards self- tailored and package tours, it was found that a vast majority of $77.2 \%$ (217 respondents) of them still preferred selftailored tours. This finding was not gender biased as the independent sample T-test was not significant at 5\% significance level. The frequency of travel has been the highest for the purpose of holiday and leisure followed by travelling for visiting friends and relatives (which is fast gaining importance) and travelling for religious purposes. Hence, tourism strategies should be formulated keeping in mind all the various high frequency purposes of visits to boost domestic tourism. Domestic travel for holiday and leisure and VFR purposes did not vary based on age, income or gender. Travelling for religious purposes showed variations based on age group. People aged between 20-30 years travelled less frequently to religious destinations. Travelling for business purposes was not biased with income or gender, but showed differences based on age. Respondents aged between 20-30 years travelled less frequently for business purposes compared to other age groups. Most respondents preferred travelling to destinations that were clean and safe and $91.1 \%$ feel that Indian

Table 4. Coefficients of independent variables

\begin{tabular}{|c|c|c|c|c|c|c|c|}
\hline & & & Coefficients $^{\mathrm{a}}$ & & & & \\
\hline \multirow[t]{2}{*}{ Model } & \multicolumn{2}{|c|}{ Unstandardized Coefficients } & \multirow{2}{*}{$\begin{array}{c}\text { Standardized Coefficients } \\
\text { Beta }\end{array}$} & \multirow[b]{2}{*}{$\mathrm{t}$} & \multirow[b]{2}{*}{ Sig. } & \multicolumn{2}{|c|}{ Collinearity Statistics } \\
\hline & B & Std.Error & & & & Tolerance & VIF \\
\hline 1 (constant) & $1.998 \mathrm{E}-016$ & .043 & .000 & 1.000 & & & \\
\hline Climatic Factor & .108 & .051 & .108 & 2.131 & .034 & .716 & 1.397 \\
\hline Price Factor & .060 & .055 & .060 & 1.082 & .280 & .605 & 1.652 \\
\hline $\begin{array}{l}\text { Destination } \\
\text { Management factor }\end{array}$ & .611 & .052 & .611 & 11.659 & .000 & .669 & 1.495 \\
\hline
\end{tabular}

a. Dependent Variable Sustainability Factor 
tourist destinations have to improve their hygiene level. A large number of respondents, however, feel a sense of satisfaction after the tour. The percentages of respondents who shop and participate in recreational activities at their destinations are commendable at $83.9 \%$ and $72.6 \%$ respectively. The above responses were all valid irrespective of various age and income groups (Table 4).

\section{Conclusion}

The forthcoming years of tourism in India with respect to sustainability need to be assessed and the government, tourism agents and destination managers should concentrate heavily on improving the destination image and current marketing activities. Destination marketing should optimise and benefit all stakeholders involved by coordinating with the tourism policies. A strategic marketing mix must be adopted in India by managing the conflicts arising from various stakeholders. It should be regarded as a technique to achieve sustainable goals foreseeing the future. An increase in the competition in destination marketing coupled with innovative tourism products and pricings would increase the number of intentional and unintentional people willing to travel domestically in India. In the $21^{\text {st }}$ century with social networking sites playing a prominent role, the new phenomenon of word-ofmouth marketing can be decisive. The managers at destinations should be wary of the fact that internet reviews about a destination are an important source of information for tourists. Thus, any positive or negative feedback arising from such sources could act as either a free sales boost or a diminishing sales factor to the tourism of that particular destination Although, travelling by package tours reduces the expenses by a $15-20 \%$ margin when compared to travelling independently (Zachariah, 2013), it is observed in this paper that Indians still prefer self-tailored tours rather than package tours. This might be because the concept of package tours is still an infant phenomenon in India (Domestic Tourism Study, 2002). Another factor that could support marketing to a large extent is the image of the destination. The government should ensure that diverse Indian tourist destination famous for its heritage, climate, etc. should sustain its image, whereas new offbeat destinations in India should focus on creating a vibrant positive image which could support its marketing. Projecting a destination for its adventure, relaxation, culture or heritage could go well with Indians as it is visible from the survey that a majority of the domestic travelers travel to destinations that portrait a similar image. Thus, practically, an in-depth understanding of shaping a destination image together with the right marketing strategies will help Indian tourism managers and the government to effectively manage sales of its destinations.

\section{Dedication}

This paper is specially dedicated to my son, Mr. Krishnan Parameswaran whose untiring support led us to publish this paper in this esteemed journal

\section{References}

Abhyankar. (2013). Growth Potential of the Domestic and International Tourism in India, Review of Integrated Business and Economic Research, 2(1), 566-576.

Amelung, N., \& Viner. (2007). Implications of global climate change for tourism flows and seasonality, Journal of Travel Research, 45(3), 285-296.

Baloglu.,\& Mangaloglu. (2001). Tourism destination images of Turkey, Egypt, Greece, and Italy as perceived by US-based tour operators and travel agents, Tourism Management, 1, 1-9.

Baloglu.,\& McCleary. (1999). A model of destination image formation, Annals of Tourism Research, 26(4), 868-897.

Berrittella, B. R.\& Tol. (2006). A general equilibrium analysis of climate change impacts on tourism, Tourism Management, 27, 913-924.

Buhalis. (2000). Marketing the competitive destination of the future, Tourism Management, 21(1), 97-116.

Chaudhary. (2000). India's image as a tourist destination a perspective of foreign tourists, Tourism Management, 21(3), 293-297.

Comrey.,\& Lee. (1992).A first course in factor analysis, Hillsdale, NJ: Erlbaum.

Crompton. (1992). Structure of vacation destination choice sets', Annals of Tourism Research, 19(3), 420-434.

Crouch. (1994). The Study of International Tourism Demand: A Survey of Practice, Journal of Travel Research, 34(4), $41-54$.

Cua, McKone.,\& Schroeder. (2001). Relationships between implementation of TQM, JIT, and TPM and manufactur- 
ing performance, Journal of Operations Management, 19(6), 675-694.

Domestic Tourism Study. (2002). Domestic Tourism Survey', National Council of Applied Economic Research, Ministry of tourism and Culture, Government of India

Edwards. (1995). Asia-Pacific Travel Forecasts to 2005, Economist Intelligence Unit, London.

Eswarappa. (2007). Changing Social Geography of Bangalore City - India: A study, Department of Geography, Bangalore University, 100-111.

Eymann.,\& Ronning. (1997). Microeconometric models of tourists' destination choice, RegionalS cience and Urban Economics, 27, 735-761.

Financial Express. (2014). Preferred holiday destinations: Indian tourists prefer Thailand, Singapore \& Malaysia over US, The Financial Express, 23 August. Retrieved from http://www.financialexpress.com/news/ preferred-holiday-destinations-indian-tourists-preferthailand-singapore-malaysia-over-us/1233695

Goh. (2012). Exploring impact of climate on tourism demand, Annals of Tourism Research, 39, 1859-1883.

Hsu, T.,\& Wu. (2009). The preference analysis for tourist choice of destination: A case study of Taiwan, Tourism Management, 30, 288-297.

India Tourism Statistics. (2012). India Tourism Statistics 2012, Ministry of Tourism, government of India, Market research division.

Jimenez, D.,\& Pulina. (2009). Estimation of outbound Italian tourism demand: A monthly dynamic EC-LAIDS model, Tourism Economics, 15, 547-565.

Juvan.,\& Dolnicar. (2014). The attitude-behaviour gap in sustainable tourism, Annals of Tourism Research, 48, 76-95.

Koppelman. (1980). Consumer analysis of travel choice, Journal of Advanced Transportation, 14(2), 133-159.

KPMG Report. (2013). Travel and tourism sector: Potential, opportunities and enabling framework for sustainable growth, KPMG, Dec 2013

Krank, S. W. W.,\& Conrod. (2011). Structural, concurrent, and predictive validity of the Substance Use Risk Profile Scale in early adolescence, Addictive Behaviors, 36, $37-46$.

Kumar. (2008). Significance of domestic tourism, Express Travel World, Jan. Retrieved fromhttp://travel.financialexpress.com/200801/management10.shtml

Lee, G. L., \& Leung. (2012). Travel motivations and travel distance with temporal advance: A case study of Hong Kong pleasure travelers, Journal of Destination Marketing \& Management, $1,107-117$.
Lise.,\& Tol. (2002). Impact of climate on tourism demand, Climatic Change, 55, 429-449.

Maddison. (2001). In search of warmer climates? The impact of climate change on flows of British tourist, Climatic Change, 49,193-208.

Martin. (2005). Weather, Climate and Tourism: A Geographical Perspective, Annals of Tourism Research, 32(3), 571-591.

Novelli, S.,\& Spencer. (2006). Networks, clusters and innovation in tourism: A UK experience, Tourism Management, 27(6),1141-1152.

Papatheodorou. (2001). Why people travel to different places, Annals of Tourism Research, 28, 164-179.

Raikkonen.,\& Honkanen. (2013). Does satisfaction with package tours lead to successful vacation experiences?, Journal of Destination Marketing \& Management, 2(2), 51-128.

Rosselló-Nadal. (2014). How to evaluate the effects of climate change on tourism, Tourism Management, 42, 334-340.

Salter. (2012). 36_Narayana Hrudayalaya Hospitals For Bringing Medical Care To The Masses.Retrieved from http://www.fastcompany.com/3017477/most-innovativecompanies- 012/36narayana-hrudayalaya-hospitals

Sharma.(2007). Kerala promotes health tourism the Ayurvedic way!, Express Travel World, Mar. Retrieved from http://travel.financialexpress.com/200703/management04.shtml

Sin. (2009). Volunteer Tourism - "Involve me and i will learn”", Annals of Tourism Research, 36(3), 480-501.

Smith., S., Mirza., Fankhauser., et al. (2001). Vulnerabilityto climate change and reasons for concern: a synthesis', in McCarthy, Canziani, Leary, Dokken and White Climate Change 2001: Impacts, Adaptation, and Vulnerability, Cambridge University Press: Cambridge.

Studenmund.(2001).Using Econometrics: A Practical Guide, 4th ed. Glen View, IL: Addison-Wesley Longman.

Tapachai.,\& Waryszak. (2000). An examination of the role of beneficial image in tourist destination selection, Journal of Travel Research, 39(1), 37-44.

Witt.,\& Witt. (1995). Forecasting tourism demand: A review of empirical research, International Journal of Forecasting, 11(3), 447-475.

Zachariah. (2013). Indians prefer home holidays as overseas travel cost rises 7\%, The Times of India, 27 June. Retrieved fromhttp://timesofindia.indiatimes.com/business/ india-business/Indians-prefer-home-holidays-as-overseastravel-cost-rises-7/articleshow/20789156.cms 


\section{Bibliography}

Bagby, P.,\& Taylor. (1994). The Twenty-Item Toronto Alexithymia Scale-1 Item Selection and Cross Validation of the Factor Structure, Journal of Psychosomatic Research, 38(1), 23-32.

Chen.,\& Xie. (2008). Online Consumer Review: Word-ofMouth as a New Element of Marketing Communication Mix, Management Science, 54(3), 477-491.

Malhotra. (2004).Marketing Research: An Applied Orientation, 4th ed. Englewood Cliffs, NJ: Prentice Hall.

Pedhazur.,\& Schmelkin. (1991).Measurement, design, and analysis: An integrated approach, Hillsdale, NJ: Erlbaum.

Tavakol.,\& Dennick. (2011). Making sense of Cronbach's alpha, International journal of medical education, 2, 53-55.
Walle. (1997). Pursuing risk or insight : Marketing Adventures, Annals of Tourism Research, 24(2), 265282 .

\section{About the Author(s)}

Radhika B. Nair is a Research Scholar at Faculty of Social Science, University of Nottingham, Malaysia.

Jayalakshmy Ramachandran is an Assistant Professor at the Faculty of Social Science, University of Nottingham, Malaysia Campus. She is a Chartered Accountant and a PhD holder in Business Management. She has publications in reputed national and international journals. 
